\title{
Staff Training and Development and Quality Education Delivery
}

\author{
Okotoni Comfort Abosede \\ Department of Educational Administration and Planning, \\ Obafemi Awolowo University, Ile-Ife, Nigeria
}

\begin{abstract}
Training and development of human resource play a critical role in ensuring the delivery of quality education at primary, secondary and tertiary levels. There is a strong correlate between school outcomes and quality of personnel entrusted to carry out the delivery of education. The quality of education at different levels in Nigeria has been a subject of debate by scholars, policy makers, educationists, parents and other stakeholders. This paper examines this concern from the perspective of staff training and development, focusing on inservice training of teachers in public secondary schools in Osun State, Nigeria. The study employed survey research design, while the study population comprised teachers in public secondary schools, officials of the State Ministry of Education and the Teaching Service Commission. One-third (10) of the Local Government Areas (LGAs) in the State were randomly selected for the study, as well as three randomly selected schools from the ten LGAs. Questionnaire and interview constituted the major research instruments for eliciting information for the study. A reliability index of 0.86 (Cronbach Alpha) was obtained on the self-designed instrument. The results showed a reasonable level in-service training and development of teachers in public schools in the state; although there were inadequacies in planning, logistics as well as deployment of resources. The paper concluded that for quality education delivery, capacity building of the personnel should be accorded a high priority.
\end{abstract}

\section{Introduction}

Training and development are key terms in the education of human resource in any organisation. [3] defined development as "the growth or realisation of a person's ability and potential through the provision of learning and educational experiences," while training is "the planned and systematic modification of behaviour through learning events, programmes and instruction which enable individuals to achieve the levels of knowledge, skill and competence needed to carry out their work effectively." According to [8], some scholars use the two concepts as synonyms, while some view the two terms as being different. [9] belong to the group of those who see the terms as being different. To them training primarily focuses on teaching organisational members how to perform their current jobs, and that development on the other hand, focuses on building the knowledge and skills of organisational members to prepare them to take on new responsibilities and challenges. For the education sector in the country to achieve its goals, close attention must be paid to effective manpower training and development.

Specifically in the Nigerian public sector, the importance of training was emphasised in the Report of the Public Service Review Commission in 1974 under the chairmanship of Chief Jerome Udoji:

A result-oriented public service will need to recruit and train specialised personnel. The new public service will require professionals who possess the requisite skills and knowledge... Training should be part of comprehensive education planning programmes... Of all the aspects of personnel management, perhaps the most important for us in Nigeria is training.

Over four decades of this report, the public service in Nigeria at various sectors is yet to accord training the priority it deserves.

Training can be broadly categorised into two types, namely, on-the- job training and off-the-job training. On-the-job training also known as direct instruction, takes various forms including apprenticeship, job rotation, internship, observation, mentoring, coaching, and learning contract, orientation, and acquaintanceship among others $[13 ; 8 ; 12]$. This type of training is not only cost 
effective, but it provides opportunities for employees to acquire multiskills through rotation as well as quick learning, though its effectiveness is limited especially in terms of exposure to external resources and facilities. Off-the-job training on the other hand is offered outside the usual workplace, employees have the opportunities of interacting and exchanging ideas with colleagues from other Figure 1 below. organisations as well as being exposed to external facilities and resources. It takes the forms of lectures, conferences, case studies, visual training and simulated programme instructions, day release, short term and long term courses among others. To attain maximum benefits from training, a systematic approach is required. This is illustrated in the

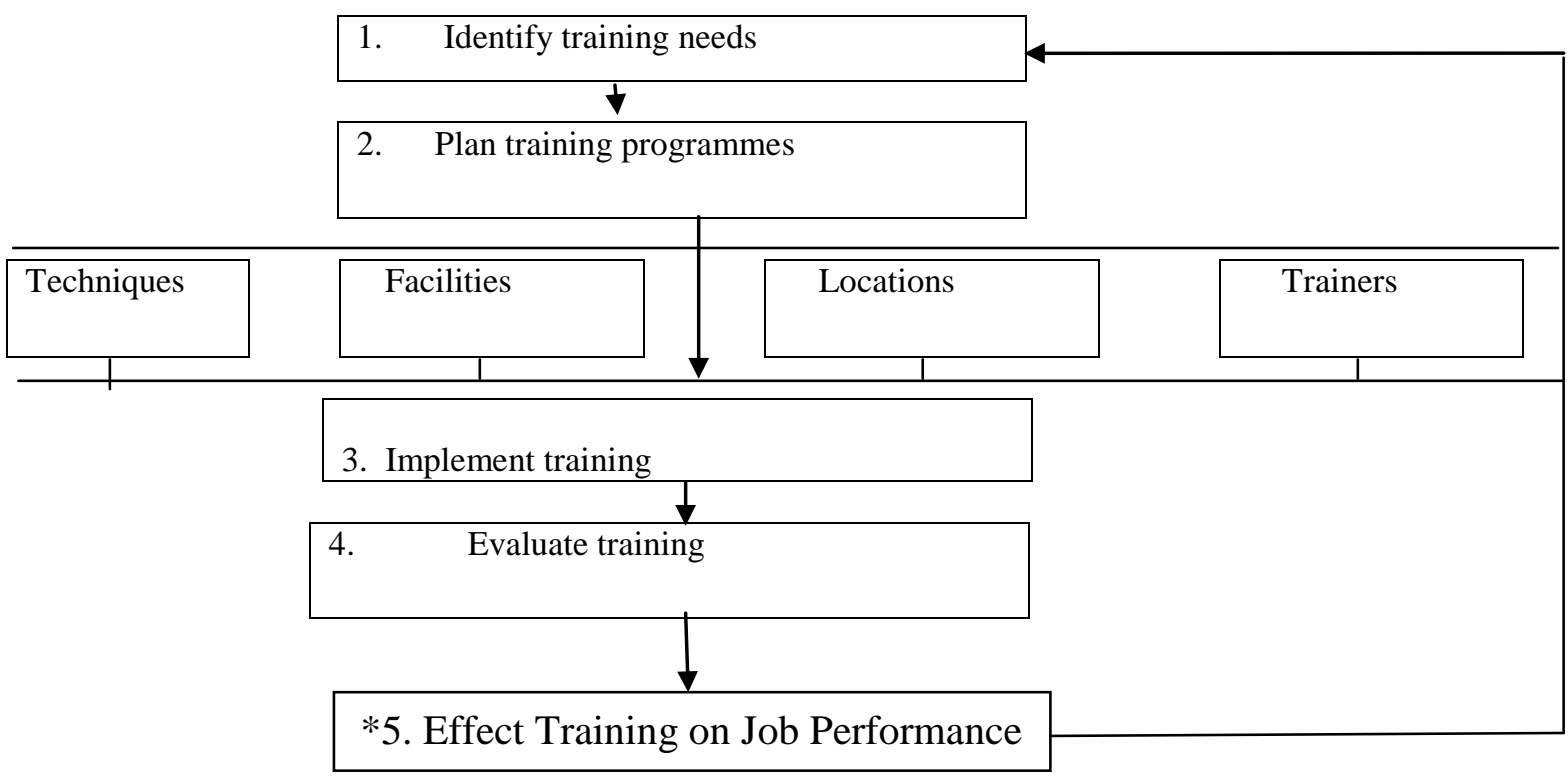

\section{Figure 1: Systematic Training Model, from the identification of training needs to the evaluation} of the training

Source: Adapted from Armstrong, M. (2006) A handbook of human resource management practice (p. 577). (10th Ed.). London: Kogan Page.

Adequate planning for training and development should start from needs identification. The needs of the organisation as well as individual staff that calls for training and development of the employees should be accorded high priority. This can result from assessment of situation on ground; facilities and equipment; changes in technology, curriculum, policies; competition; and general global demands to keep abreast of time. The needs most often dictate the programmes to put in place to solve the problems. Incorporated in the plans should be the timing, techniques, facilities, location, and the trainers, all tailored to the identified needs. Having put all in place, adequate implementation should follow, with control measures put in place to monitor progress and attainment of objectives of the programmes. This should be followed by evaluation of the programmes to ascertain the required outcomes for training and if need be a retraining. This model has been employed to guide this study.

Human Resource Management promotes the idea that human capability and commitment is the distinguishing factor between successful organisations and the unsuccessful ones. The role of the teacher in the educational system cannot be over emphasised, this is reiterated by [1] that "no school system can be higher in quality than the level of motivation and job commitment of teachers within the system." Therefore, not only is capability/quality important, but also commitment to the job. The two must go together.

\section{Objectives of the Study}

The objectives of the study were to assess the level of staff training and development, examine the needs for training; modes of staff training; implementation and evaluation of training; and to 
appraise the constraints faced by the teachers/government in staff training and development programmes.

\section{Methodology}

The descriptive survey research design was employed for the study. The population comprised teachers in public secondary schools in Osun State, officials of the State Ministry of Education and the Teaching Service Commission (TESCOM). Onethird (10) of the Local Government Areas (LGAs) in the State were randomly selected for the study, while three schools were randomly selected from the ten LGAs. In each school, the principal and five teachers were selected. The principals were purposively sampled as the heads of the schools, while the teachers were chosen using stratified random sampling, that is, a teacher each from the languages, sciences, arts, social sciences and vocational departments. Two officials each from the Ministry of Education and the Teaching Service Commission were purposively selected being officers in the personnel units. Questionnaire and interview constituted the research instruments for eliciting information for the study. Questionnaire was used in sourcing data from the teachers, while interviews were conducted for the principals and the ministry officials. A reliability scale of 0.86 was obtained for the instrument using the Cronbach Alpha. Data were analysed using mean, percentages and Chi-Square tests.

A set of questionnaire titled 'Staff Training and Development Issues' (STDI) was self-designed to obtain data from the teachers in the selected schools. It was divided into 4 sections after the Systematic Training Model of [3]. Each section had questions on the different aspects of the training model. Section A elicited information on bio data to cross check information on staff training requirements, and other training facts. Section B on training needs identification, Section $\mathrm{C}$ on training programme assessment and Section D on methods of evaluating effects of training programmes. Interviews were conducted to generate data on the human training and development programmes and to examine some level of corroboration with the official documents from the Ministry of Education and Post Primary Schools Board. Data were also obtained from secondary sources, such as government white papers, guidelines and circulars.

\section{Staff Training and Development: Government's Perspective}

Over the years, government has come to realise the need for result-oriented public service that will make use of modern management techniques to achieve policy objectives and programmes. The realisation brought about the need for government to engage in virile manpower development in order to advance the socio-economic development of the nation at the various levels and sectors including education. The government seems to have come to terms with the paradigm shift of having human resources as the greatest asset of an organisation. The 1988 Civil Service Reforms of the Federal Government emphasised staff training as a right and made it mandatory that $10 \%$ of Total Personnel vote of Expenditure be expended on Staff Training and development; however, the implementation has been contentious. The centralisation of the trainings in the Bureau of Establishments and Training must have contributed to its ineffective implementation; it requires serious decentralisation for the programmes to be successful and effective.

Government's Objectives of Staff Training and Development among others include were to:

a. allow employees to acquire skills and requisite knowledge necessary for the daily performance of jobs;

b. encourage the right attitudes to work through training and to cultivate habits likely to contribute positively to the effective running of the Offices;

c. enable individuals to achieve potentials within the organisation, and to help satisfy individual aspirations and desires;

d. enable employees to acquire new skills to facilitate career mobility and to be able to cope with tasks in the new duty schedules.

To achieve these objectives and enhance training effectiveness, government at different times at different levels has embarked on several training reforms that is divergent from the formal sporadic and unstructured form. Public officers are to be exposed to one type of training or the other and at specified intervals during his/her career. As above the training was not to be once and for all, It was also to meet the changing technology; needs; curriculum policies; globalisation; structural and economic changes. To stress the importance attached to employees' training, successful participation in prescribed training programmes was made a prerequisite to crossing from one cadre to the other. Among other policy objectives of inservice training is the policy that individual 
employee who wishes to improve his academic achievements or acquire additional professional qualifications will be assisted by granting him/her leave without pay, depending on the exigencies of service at the period of application.

\section{Staff Training and Development: Implications for Quality Education Delivery}

Suffice it to say that the teacher is a major factor and force in the delivery of quality education. Studies have identified teacher effects on students' achievements as superseding school effects [12]. With regards to this, attention has been drawn to teacher quality and instructional effectiveness. The importance of teacher training and development is seen in these attributes, which have direct and indirect links with quality of education delivery:

- Competence of teachers to carry out their work effectively through knowledge and skills acquisition.

- Modification of behaviour through learning experiences.

- Knowledge on how to perform current jobs.

- Updating knowledge to cope with educational reforms and curriculum changes.

- Increasing confidence, motivation and commitment.

- Enhancing responsibility.

- Personal satisfaction of staff through the development.

- Improved quality of staff.

- Keeping up-to-date with ICT/Technologies generally

The success of the educational enterprise is matched to the quality of the teachers who carry out the instructional tasks.

\subsection{Results and Findings of the Study}

This section presents the results and findings of the study as well as the discussions.

\section{Section A}

The age group of the respondents showed a population that could benefit highly from the programmes and who could contribute meaningfully to the education system of Osun State if the programmes were adequately organised and implemented. Age range of $24-45$ constituted $54.2 \%$, while $46-60$ made up $43 \%$. Three percent did not declare their ages. The age range shows that a significant percent (54.2) still have many years to serve before retirement at age 60 . The academic qualifications indicated National Certificate in Education (NCE) - 16.2\%; holders of Bachelor in Education (61.3\%); Higher National Diploma holders $(7.7 \%)$; Master degree holders $(7.7 \%)$, and no response $(0.7 \%)$. The data indicated that $77.5 \%$ of the respondents had the right educational qualifications for teaching. Although, this does not in any way suggests that they would not require training and development as every category of teachers needs training and development to remain current on the job and be able to contribute maximally to the objectives of education. Quite a large percentage of 1-10 years of teaching experience $(56.4 \%)$ need benefit from induction training and refresher courses to keep up-to-date with modern technology and curricula innovations in education.

Table 2 shows the level of staff training in Osun State. It can be observed from the Table that $31 \%$ of the teachers indicated that they had attended conferences/seminar/workshops since taking up their teaching appointments, while $69 \%$ had no such opportunity. The conferences were not tailored to the individual, school or community needs. Self sponsorship (100\%) also shows that the individuals applied for whatever course that they deemed fit.

Forty-three percent of the sample had National Diploma, Higher National Diploma and National Certificate in Education. These groups need much to benefit from the training programmes because, as much as the government is trying to fill the sector with specialists in education field, those already employed without the required qualification(s) could only be given time to get qualified, and for those in the NCE cadre to get additional qualifications to meet up with the requirement for first degree in education. Sixty (42\%) respondents had acquired additional qualifications since joining the work force; this could mean a lack of spread or equal opportunities for all.

However, the modes of sponsorship and release raise a point of concern in terms of meeting the needs of the school and education objectives. Those who have additional qualifications sponsored themselves and were allowed to run the programmes only during the holidays. These signify that the programmes may not be school needs based in terms of the required subject areas, but the individual teacher's attempt at selfdevelopment. 
Table 1: Socio-Demographic information on the teachers

\begin{tabular}{|l|l|l|l|}
\hline Variable & Levels & Frequency (f) & Percentage (\%) \\
\hline \multirow{4}{*}{ Age Range } & $24-35$ & 55 & 38.7 \\
\cline { 2 - 4 } & $36-45$ & 22 & 15.5 \\
\cline { 2 - 4 } & $46-55$ & 47 & 33.1 \\
\cline { 2 - 4 } & $56-60$ & 14 & 9.9 \\
\cline { 2 - 4 } & No Response & 4 & 2.8 \\
\cline { 2 - 4 } & Total & 142 & 100.0 \\
\hline \multirow{4}{*}{ Academic Qualifications } & NCE & 23 & 16.2 \\
\cline { 2 - 4 } & B.ED/B.SC.ED & 87 & 61.3 \\
\cline { 2 - 4 } & PGDE & 9 & 6.3 \\
\cline { 2 - 4 } & HND & 11 & 7.8 \\
\cline { 2 - 4 } & Master Degree & 11 & 7.8 \\
\cline { 2 - 4 } & No Response & 1 & .7 \\
\cline { 2 - 4 } & Total & 142 & 100.0 \\
\hline \multirow{4}{*}{ Experience } & $1-5$ & 64 & 11.3 \\
\cline { 2 - 4 } & $6-10$ & 16 & 9.1 \\
\cline { 2 - 4 } & $11-15$ & 13 & 6.3 \\
\cline { 2 - 4 } & $16-20$ & 9 & 11.3 \\
\cline { 2 - 4 } & $21-25$ & 16 & 8.5 \\
\cline { 2 - 4 } & $26-30$ & 12 & 100.0 \\
\cline { 2 - 4 } & No Response & 142 & \\
\cline { 2 - 4 } & Total & & .2 \\
\hline
\end{tabular}

Research Question 1: What is the level of staff training in Osun State?

Table 2: Level of staff training in Osun State

\begin{tabular}{|c|c|c|c|}
\hline Items & Responses & Frequency (f) & Percentage (\%) \\
\hline \multirow{3}{*}{$\begin{array}{l}\text { Have you ever attended } \\
\text { conferences/seminar/workshops since } \\
\text { taking up this appointment }\end{array}$} & Yes & 44 & 31 \\
\hline & No & 98 & 69 \\
\hline & Total & 142 & 100.0 \\
\hline \multirow{6}{*}{$\begin{array}{l}\text { What was your educational } \\
\text { qualification at the time of your } \\
\text { employment? }\end{array}$} & B. Sc/B.A/B. Tech & 15 & 10.6 \\
\hline & M.A. Ed & 4 & 2.8 \\
\hline & B.A. Ed/B. Ed/B.SC. Ed & 42 & 29.6 \\
\hline & HND & 19 & 13.4 \\
\hline & NCE & 38 & 26.8 \\
\hline & OND & 4 & 2.8 \\
\hline \multirow{6}{*}{$\begin{array}{l}\text { Have you obtained additional } \\
\text { qualification since your employment? }\end{array}$} & PGDE & 20 & 14.1 \\
\hline & Total & 142 & 100.0 \\
\hline & Yes & 60 & 42.3 \\
\hline & No & 82 & 57.7 \\
\hline & Total & 142 & 100.0 \\
\hline & B. Sc/B. Tech & 3 & 5.0 \\
\hline \multirow{3}{*}{ What is your qualification now? } & B.A. Ed/B. Ed/B.Sc. Ed & 34 & 56.7 \\
\hline & M.A. Ed/M. Ed/M. Sc & 11 & 18.3 \\
\hline & MPA/PGDE & 12 & 20 \\
\hline
\end{tabular}




\begin{tabular}{llll}
\hline & Total & 60 & 100.0 \\
& Study leave with pay & - & - \\
How was the additional qualification & Study leave without pay & - & - \\
obtained (mode of sponsorship)? & Scholarship & - & - \\
& Self-Sponsorship & 60 & 100 \\
& Total & 60 & 100.0 \\
What was the mode of release for the & Day release & - & - \\
study? & Half-day release & - & - \\
& Entire period of training & - & - \\
& Some days in a week & - & - \\
& Holiday period & 60 & 100 \\
& Total & 60 & 100 \\
\hline
\end{tabular}

Research Question 2: What are the dynamics/issues in staff training and development?

Table 3: Dynamics/issues in staff training and development

\begin{tabular}{|c|c|c|c|}
\hline Items & Responses & Frequency (f) & Percentage $(\%)$ \\
\hline \multirow[b]{2}{*}{$\begin{array}{l}\text { What dictates your selection for such } \\
\text { programme? }\end{array}$} & Years of service & 2 & 4.5 \\
\hline & $\begin{array}{l}\text { Subject area } \\
\text { specialisation } \\
\text { School needs } \\
\text { Status in school } \\
\text { Total } \\
\text { Discussion }\end{array}$ & $\begin{array}{l}32 \\
- \\
10 \\
44 \\
28\end{array}$ & $\begin{array}{l}72.7 \\
- \\
22.7 \\
100.0 \\
44.4\end{array}$ \\
\hline $\begin{array}{l}\text { What training techniques are } \\
\text { employed for the programmes you } \\
\text { have participated in? }\end{array}$ & $\begin{array}{l}\text { Lecture } \\
\text { Talks } \\
\text { Simulation } \\
\text { Practical Demonstration } \\
\text { Role play }\end{array}$ & $\begin{array}{l}36 \\
4 \\
6 \\
7 \\
3\end{array}$ & $\begin{array}{l}57.2 \\
6.4 \\
9.6 \\
11.1 \\
4.8\end{array}$ \\
\hline \multicolumn{4}{|c|}{ Please rate the following according to their convenience } \\
\hline & Fair & 30 & 68.1 \\
\hline Location of the training & $\begin{array}{l}\text { Good } \\
\text { Excellent } \\
\text { Total } \\
\text { Poor }\end{array}$ & $\begin{array}{l}9 \\
5 \\
44 \\
20\end{array}$ & $\begin{array}{l}20.5 \\
11.4 \\
100.0 \\
45.5\end{array}$ \\
\hline Facilities & $\begin{array}{l}\text { Fair } \\
\text { Good } \\
\text { Excellent } \\
\text { Total } \\
\text { Poor }\end{array}$ & $\begin{array}{l}19 \\
5 \\
- \\
44 \\
6\end{array}$ & $\begin{array}{l}43.2 \\
11.4 \\
- \\
100.0 \\
13.6\end{array}$ \\
\hline Training Techniques & $\begin{array}{l}\text { Fair } \\
\text { Good } \\
\text { Excellent } \\
\text { Total } \\
\text { Fair }\end{array}$ & $\begin{array}{l}28 \\
10 \\
- \\
44 \\
16\end{array}$ & $\begin{array}{l}63.6 \\
22.7 \\
- \\
100.0 \\
36.4\end{array}$ \\
\hline Trainers & $\begin{array}{l}\text { Good } \\
\text { Excellent } \\
\text { Total }\end{array}$ & $\begin{array}{l}22 \\
6 \\
44\end{array}$ & $\begin{array}{l}50 \\
13.6 \\
100.0\end{array}$ \\
\hline
\end{tabular}


Table 3 shows that subject area of specialization formed the major basis for selection for training $(72.7 \%)$ for seminars, workshops and conferences. Most of the locations were rated fairly convenient $(68.1 \%)$, while the facilities were rated between poor and fair, $45.5 \%$ and $43.2 \%$ respectively. Training techniques were mostly rated as being fair $(63.6 \%)$. However, the trainers were regarded as $\operatorname{good}(50 \%)$, and fair $(36.6 \%)$.

Research Question 3: What are the determining factors for staff training in the State?

Table 4: The determining factors for staff training in the State

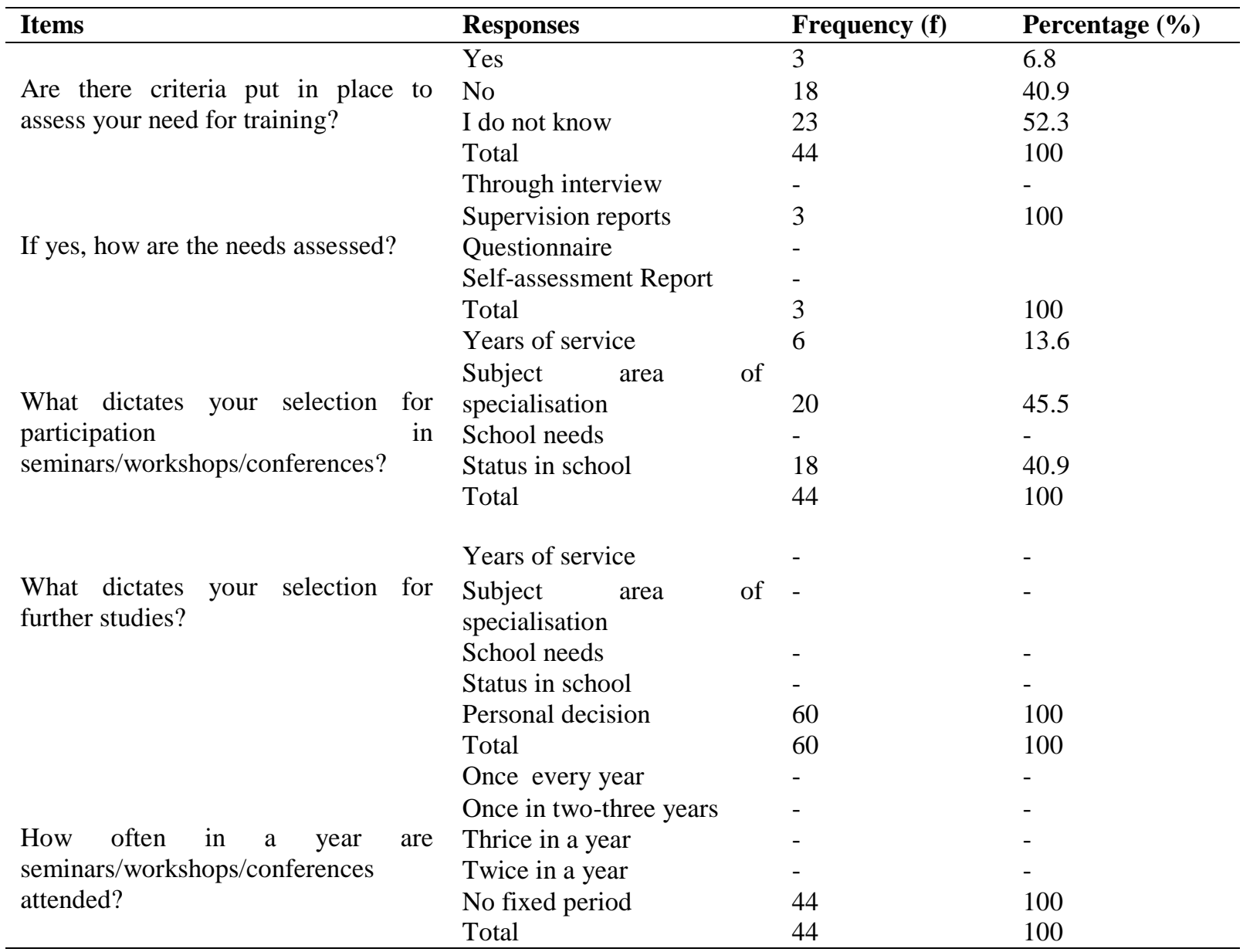

Table 4 indicates that most respondents did not know or were of the opinion that there were no criteria put in place to assess training needs $(52.3 \%$, $40.9 \%$ respectively). There was a consensus on no fixed period for the attendance of such programmes.

Table 5 shows the outcomes of staff participation in training programmes, and additional qualifications obtained by teachers in the state. From the responses, staff were not promoted after the completion of the training programmes, the outcome attracted no rise in pay neither were they given higher responsibilities. This could be attributed to the fact that most respondents had selfsponsorship, although approval was obtained from the Teaching Service Commission of the State. The situation calls for urgent review so that training can serve as incentives to beneficiaries.

Table 6 on the evaluation techniques and procedure employed in assessing development training programmes in the state shows that the respondents were not aware of evaluation techniques used by government in evaluating outcomes of the training programmes. 
Research Question 4: What are the outcomes of such programmes on the staff?

Table 5: Outcomes of training programmes on the staff

\begin{tabular}{lllll}
\hline Items & Responses & Frequency (f) & Percentage (\%) \\
\hline \multirow{2}{*}{$\begin{array}{l}\text { Were you promoted after completing } \\
\text { the programme? }\end{array}$} & No & 60 & 100 \\
& & Yes & - & - \\
& & Total & 60 & 100 \\
Any rise in pay given after the & Yes & 60 & 100 \\
programme? & & - & - & 100 \\
Were you given higher & No & 60 & 100 \\
responsibilities after & the & Yes & 60 & - \\
programme(s)? & & Total & - & 100 \\
\hline
\end{tabular}

Research Question 5: What are the evaluation techniques to assess such programmes?

Table 6: Evaluation techniques and procedures

\begin{tabular}{|c|c|c|c|}
\hline Items & Responses & Frequency (f) & Percentage (\%) \\
\hline \multirow{4}{*}{$\begin{array}{l}\text { Is there usually an evaluation of the } \\
\text { training programme(s)? }\end{array}$} & No & 12 & 27.3 \\
\hline & Yes & - & \\
\hline & I do not know & 32 & 72.7 \\
\hline & Total & 44 & 100.0 \\
\hline \multirow{9}{*}{$\begin{array}{l}\text { How soon after training are the } \\
\text { programmes evaluated by } \\
\text { government via the agencies, e.g. } \\
\text { the Teaching Service Commission? }\end{array}$} & 2-4 Months & - & - \\
\hline & Immediately after the training & - & - \\
\hline & No form of evaluation & 7 & 15.9 \\
\hline & On term basis & - & - \\
\hline & No response & 37 & 84.1 \\
\hline & Total & 44 & 100.0 \\
\hline & Interview & - & - \\
\hline & $\begin{array}{l}\text { Distribution of questionnaire to } \\
\text { obtain responses }\end{array}$ & - & - \\
\hline & $\begin{array}{l}\text { Inspection by government } \\
\text { officials }\end{array}$ & - & - \\
\hline \multirow{6}{*}{$\begin{array}{l}\text { In what ways are the training } \\
\text { programmes evaluated by the } \\
\text { Ministry of Education or Bodies in } \\
\text { charge? }\end{array}$} & Short examination after training & - & - \\
\hline & No form of evaluation & 7 & 15.9 \\
\hline & Through promotion examination & - & \\
\hline & & & 5.9 \\
\hline & I do not know & 37 & 84.1 \\
\hline & Total & 44 & 100 \\
\hline
\end{tabular}

Research Question 6: What are the constraints to staff training and development in the State?

Table 7: Staff challenges on training and development

\begin{tabular}{lll}
\hline Reasons/constraints & Frequency & Percentage \\
\hline Financial & 124 & 87.3 \\
Time factor & 109 & 76.8 \\
$\begin{array}{l}\text { No permission from the government/long protocol in getting } \\
\text { permission }\end{array}$ & 122 & 85.9 \\
Studies not attracting higher pay/promotion & 78 & 54.9 \\
\hline
\end{tabular}




\section{Discussion of Results}

An examination of data on training/development of teachers showed that, participation in workshops and conferences received inadequate attention. Sixty-nine percent of the teachers had never attended any workshop or conference, while $31 \%$ had participated in workshops/conferences. This is contrary to the Human Resource Model, which emphasises human beings as assets. Thus, investment in training and development and adoption of commitment strategies are necessities in order to "ensure that highly skilled and loyal employees give the organization a competitive advantage" [6]. The multiplier effect of the apparent poor attention to training could be felt on the effectiveness of the teachers and delivery of quality education in the State. Considering the importance of teacher effects on school outcomes, the factor of teacher motivation through adequate training and development ought to be explored maximally.

Results further showed that the needs of the individuals and the schools did not form the basis for training and development of teachers. Teachers were selected on the basis of subject areas of specialisation and status, that is, the position occupied by staff, thus, conferences were organised for Principals and Vice Principals across board in the State. Staff that took courses leading to higher qualifications undertook the training at their own expense. This could lead to staff attrition and internal brain drain. Institutional needs fulfilment was not the basis for staff proceeding on further studies.

Results further showed that there was no provision for post-training assessment and evaluation, which has often contributed to the lackadaisical attitude of beneficiaries to training and participation in workshops/seminars. An urgent step is required to address this and to put in place appropriate measures to make beneficiaries more responsive to justify the money expended in trainings. Table 7 indicates the challenges confronting training and development of teachers in the State. These include finance, time factor and the undue bureaucratic delay in obtaining approval for further studies. This was traceable to the fact that requests for the release of officers had to be processed through the Bureau of Establishments and Training. Agencies/Departments under the Bureau had to get necessary approval before releasing the officers (Circular issued in September 1990 and February, 1993).
Completion of training in one field or the other in some cases attracted no higher pay, not only this such officers had to convert from one cadre to another, a process that had attached to it a policy that steps down the next available promotion in order to mainstream with the required cadre, but giving room for more years of service before retirement. This is corroborated in the findings of a study carried out by [2]; not only were the teachers not motivated to pursue further studies; their efforts were not recognised/appreciated by government as the training did not attract increase in pay and promotion. It was even made ridiculous by demotion owing to the policy of 'conversion to the graduate cadre,' and subsequently being made to wait for a period of about three years (as the case is in the state under study) before the next promotion could take place.

The major problem confronted by the government in realising her enviable laudable objectives is funding. It manifested in getting a befitting site for staff training as the centre is housed in a school premises. According to the government paper, inadequate accommodation has reduced the scope of its performance compared to what obtains in other training Centres in the Federation. Poor staffing and training facilities were also identified, the centre lacked modern training facilities and equipment like language laboratories computers and libraries.

\section{Conclusion}

The study concludes that Osun State has at different times made efforts at organising training for teachers in public schools since its inception in 1992. The efforts, however, have not yielded the desired results due to several challenges confronting the efforts ranging from inadequate funding to poor facilities, absence of post-training evaluation and appraisal, lackadaisical attitude of some beneficiaries because trainings do not attract increase in pay and higher responsibilities.

\section{Policy Recommendations}

- It is imperative that a comprehensive training policy for teachers be formulated that will address key components of training, such as training needs, procedure for selection, funding, training methods, and evaluation among others. This will provide a clear distinction of the Education Sector staff training policies from Civil Service policies on training and development. 
- It is recommended that the government put in place quality control for training of teachers such that will ensure the quality of training given to teachers in the state.

- Training and retraining should be encouraged among principals and educationists to update their knowledge on instructional leadership and on-the- job training.

- Adequate funding of education through active involvement of all stakeholders, especially by strengthening Public Private Initiatives in raising funds for staff training and development.

- There is the need to make provision for utilizing of knowledge acquired from training, so that the money expended will not be a waste.

- Principals, senior staff and resource persons could be made use of in the training of colleagues through orientation and in-house refresher courses.

\section{References}

[1] Adelabu, M. A. Teacher Motivation and Incentives in Nigeria, At www.eldis.org/go/topics/resources-guides... (2007).

[2] A. D. O. Adesina, and B. A. Adeyemi, "Teachers and Nation Building: Factors against Achievement of Purpose." The Journal of Theory and Research in Education. (2002). 7 (1), p. 29

[3] Armstrong, M. A Handbook of Human Resource Management Practice., (10th Ed.). Kogan Page, London, (2006).

[4] P. Boxall, and J. Purcell, "Strategic Human Resource Management: Where Have we Come from and Where Should we be Going?", International Journal of Management Reviews, (2000). 2(2), pp. 183-203.

[5] Federal Republic of Nigeria. Revised Guidelines for Training in the Federal Civil Service. Office of Establishments and Management Services: Lagos, (1995).

[6] Korean Educational Development Institute. Journal of Educational Policy. (2008), 5(2).p. 5.

[7] Mullins, L. J. Management and Organizational Behaviour. ( $5^{\text {th }}$ Ed.), Prentice Hall, London, (1999).

[8] O. Okotoni, and J. Erero "Manpower Training and Development in the Nigerian Public Service". African Journal of Public Administration and Management. (2005). XVI (1), 1-13.
[9] Jones, G.R., J.M. George, and C.W.L. Hill. Contemporary Management, (2 ${ }^{\text {nd }}$ Eds.), Irwin McGraw Hill, Boston, (2000).

[10] Peretomode, V. F. (Ed.). Introduction to Educational Administration Planning and Supervision. Joja Educational Research and Publishers Ltd. Lagos, (2004).

[11] Riches, C. and C. Morgan, (Ed.). Human Resource Management in Education. The Open University, Philadelphia, (1989).

[12] Teddlie, C. and D. Reynold. In Science Direct Teaching and Teacher Education: Teacher Behaviour and Student Outcome. Retrieved May 17,2010, from http://www.teachersmind.com/education.htm.

[13] Vasishth, N. (2 ${ }^{\text {nd }}$ Ed). Students' Guide to Management. Taxmann Allied Services. Pvt Ltd. India, (2003) p. 323. 